\title{
A CASE STUDY ON PERFORMANCE EVALUATION OF GRID CONNECTED PV GENERATION SYSTEM IN UAE
}

\author{
Swaroop . $\mathbf{R}^{1}$ \\ ${ }^{I}$ Assistant Professor, Department of Electronics, Amity University, Dubai Campus, UAE
}

\begin{abstract}
Energy is an important aspect in the today's world. Due to the increase in the population and the decrease in oil and other energy resources the power generation using renewable energy has become more popular. The proper paper presents the feasibility analysis of implementing the photovoltaic system for a residential house in UAE using a grid connected system. In this paper real data for a typical residential house with the present electricity cost in UAE is taken in to consideration for the analysis. RET screen software has been used for the economic analysis. The software has also been used to get the climatic conditions like humidity, temperature with the radiations. The effect of these conditions with the efficiency of the solar panels was also analyzed.
\end{abstract}

Keywords: Photovoltaic system, RET screen, Feasibility, Energy Analysis.

\section{INTRODUCTION}

Renewable energy today is becoming more and more popular because of the fluctuation in the oil prices. Photovoltaics and Wind mill are today very popular alternate energy sources as it is a clean energy and abundant in supply. The costs of the PV cells are also decreasing day by day. Photovoltaic system mainly uses PV cells which when incident with photons from sun light break the bonds and releases electrons. These electrons flow in the circuit as $\mathrm{DC}$ current. The inverters are used to convert the DC to AC for residential power. Today solar technology has developed in many ways ranging from multiple tracking PV system where the sun is tracked by dual axis. Today concentrating solar cells are used in which the sunlight is focused using dish to concentrate the light and when the light falls in to the cells part of the energy is converted to electrical energy. The rest of the energy is either reflected or absorbed. The efficiency of the PV cells range from $15 \%$ to $20 \%$ and hence more number of panels have to be added to get the required power. There are lots of research going on to bring the efficiency higher. [1,3]]. Some of the other areas of research include thin film cells, flexible panels, building integrated PV systems. Researches are going on in the areas of rectenna called nano anteno to convert sun light to DC directly. Though the efficiency of these type of panels are $\& 0 \%$ theoretically practically the NREL has achieved only $1 \%$.

The figure 1 below shows the equivalent circuit for PV cell in which the current source indicates that the current flow when the light falls on the PV cell. The Rs and Rsh are the series and parallel resistance appearing across the cell. These are the resistance by the conductors. The figure 2 shows that the characteristics of PV in which it is seen that the voltage and current varies according to the variation in the incident sunlight and the red indicates the another set of V-I characteristics for different temperature which is 56 degree centigrade.[2] It is seen that as the temperature increases above 25 degree centigrade the performance is reduced. The optimal working condition of PV cell is 25 degree centigrade.

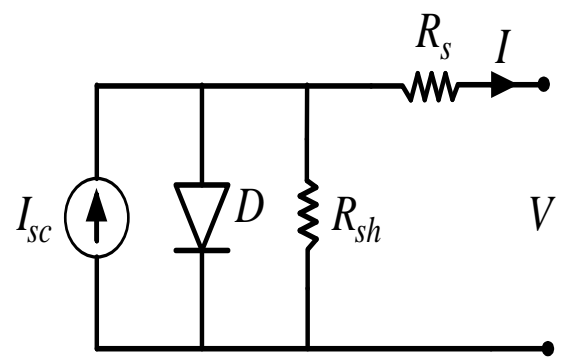

Fig 1: Equivalent circuit of array.

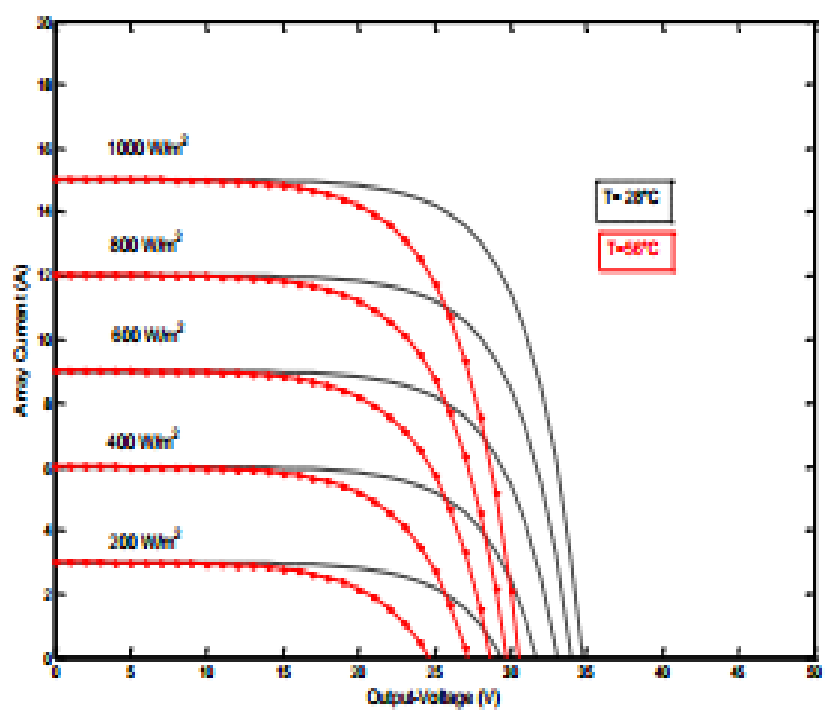

Fig 2: Characterisitics of PV for different irradiance and temperature 


\section{SOLAR CELL EFFICIENCY}

The figure 3 below shows the efficiency of the solar cells. It can be seen from the graph that the efficiency has been reached until $24 \%$. The efficiency of the solar panels mainly depends on open circuit voltage, short circuit current Fill Factor and power input. The formula governing the effificny is given below. Here Voc is the open circuit voltage which is the maximum voltage across the panels when the terminals are open, Isc is the short circuit current which is the current flowing through the terminals when it is shorted. The fill factor is the maximum area that can be fitted inside the curve, $\mathrm{k}$ stands for the boltsman constant. Vmp and Imp is the peak values of Voc and and Isc where the power is maximum and $\mathrm{q}$ is the elementary charge. $[2,5,6]$

$$
\eta=\frac{V_{O C} I_{S C} F F}{P_{\text {in }}}
$$

$$
\begin{gathered}
V_{M P}=V_{O C}-\frac{n k T}{q} \ln \left(\frac{V_{m p}}{n k T / q}+1\right) \\
F F=\frac{V_{O C}-\ln \left(V_{O C}+0.72\right)}{V_{O C}+1} \\
V_{O C}=\frac{q}{n k T} V_{O C} \\
F F=\frac{V_{M P} I_{M P}}{V_{O C} I_{S C}}
\end{gathered}
$$

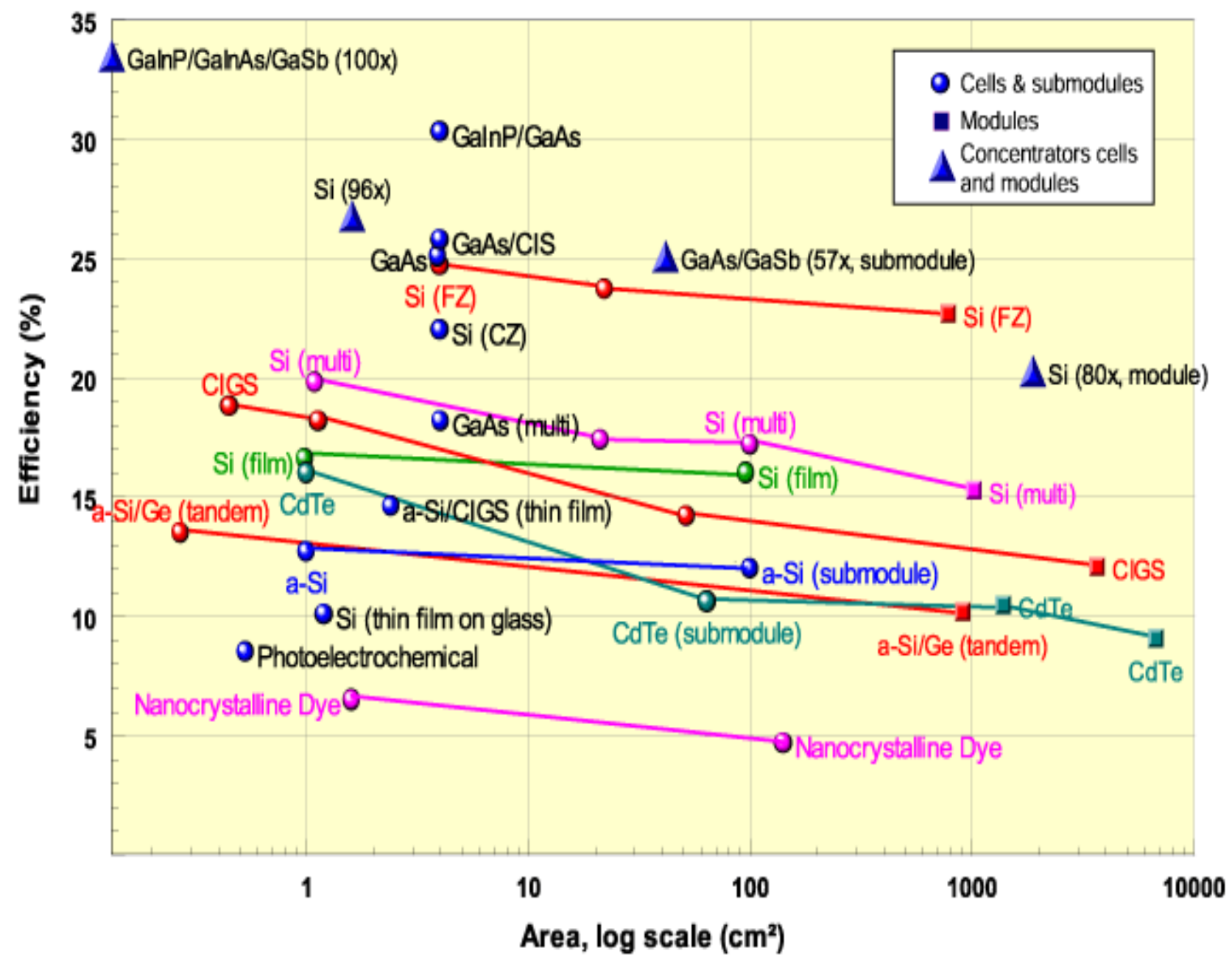

Fig 3: Efficiency of various types of solar cells

\section{DESIGN OF PHOTOVOLTAIC SYSTEM}

The figure 4 shows the variation of average earth and air temperature every month. It can be seen that the temperature rises in the month of June July and august. The temperature affects the performance of photovoltaic as the ambient temperature to get the maximum efficiency is 25 degree centigrade. 


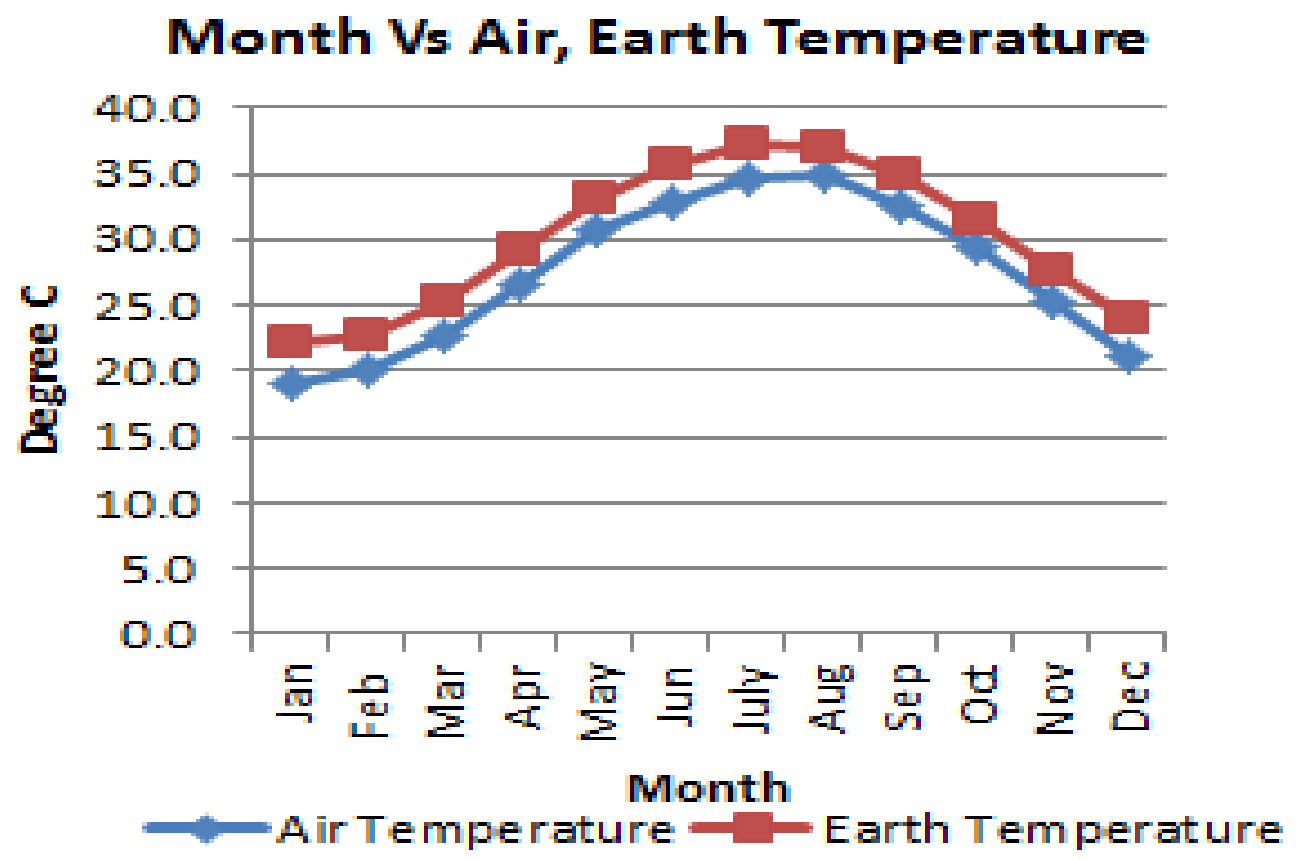

Fig 4: Month Vs Air temperature

The figure 5 shows the variation of solar radiation and wind speed for every month and it can be observed that the solar radiation is high in UAE and also the wind speed is almost constant. The wind speed also affects the performance of the panels. The sand storm due to wind deposits the sand dust in panels which also highly reduce the performance of the PV panels.

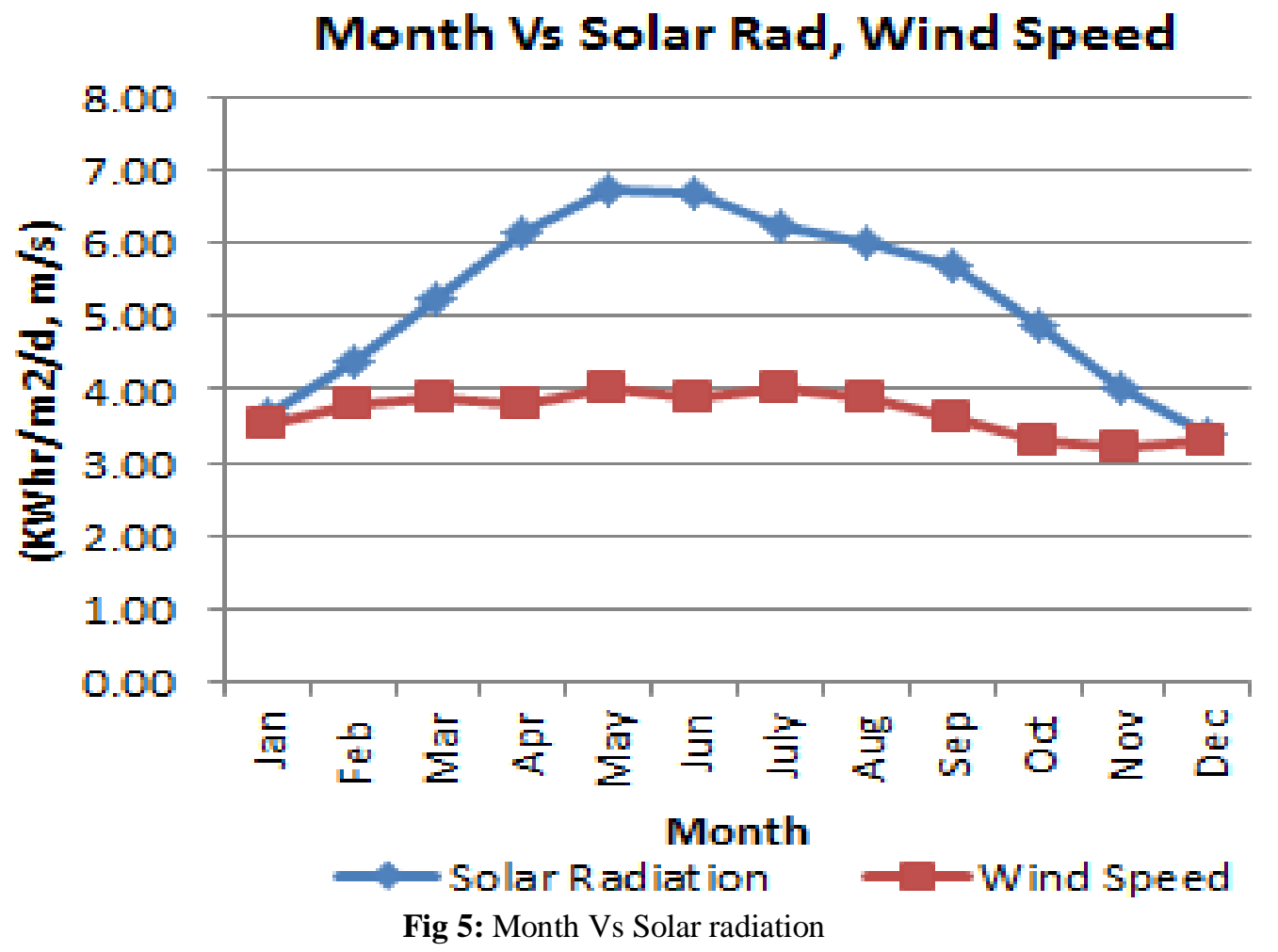

The wind between the panels and roof creates pressure on the panels which creates force and finally damage the panels. The effect of snow is not considered in this paper but the snow also significantly affects the panel performance one is the deposit and the other is the weight of snow deposited in the panels. The figure 6 shows the load for every month to be connected to the PV system. The average load is approximately $4 \mathrm{KW}$. The load varies as per the climatic situations. The typical load from the month of May to September is high due to summer and it shows low in august as most of the residents in UAE will be on vacation. 


\section{Month Vs Load}

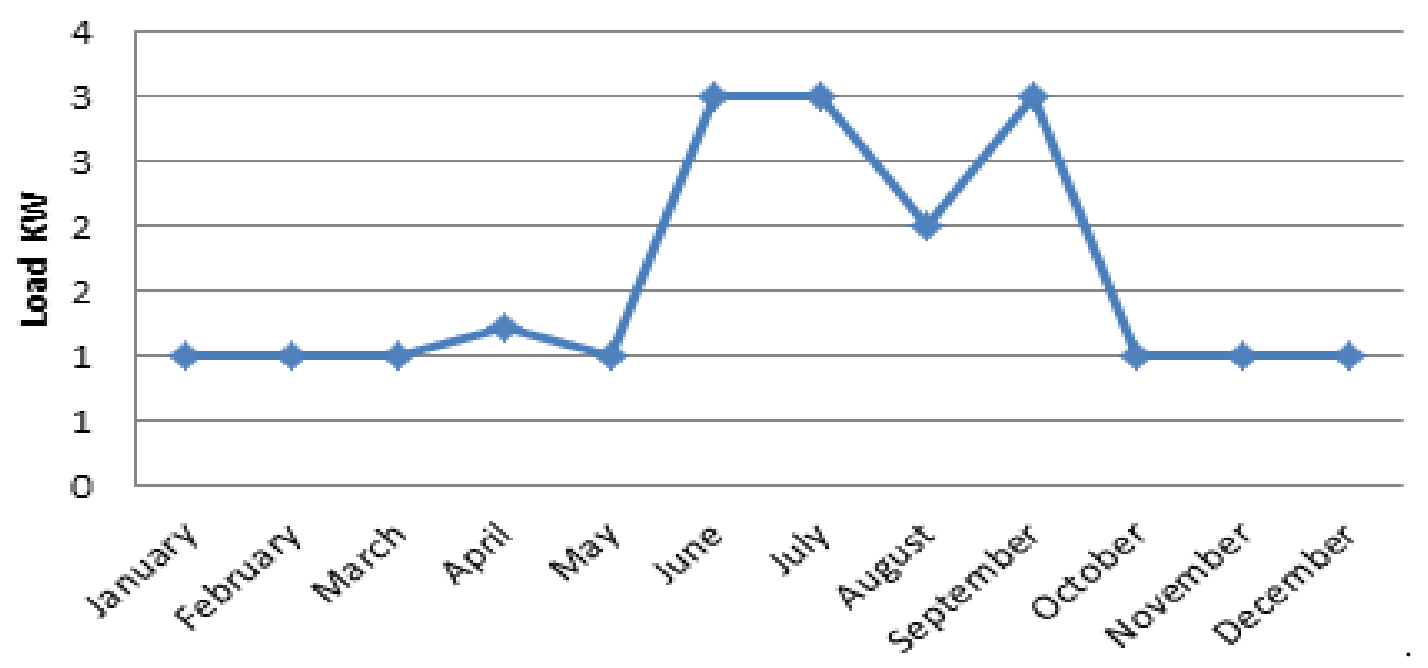

Fig 6: Month Vs Load

\section{DESIGN USING RET SCREEN SOFTWARE}

The following table shows the amount of solar radiation incident every month and how much electricity can be exported to the grid. The angle of tilt is kept at 25 which is approximately equal to latitude and the azimuth angle is set as 25 degree.

Table 1- Electricity exported to grid and the solar radiation

\begin{tabular}{|c|c|c|c|c|}
\hline Month & $\begin{array}{c}\text { Daily solar radiation - } \\
\text { horizontal } \\
\mathrm{kWh} / \mathrm{m}^{2} / \mathrm{d}\end{array}$ & $\begin{array}{c}\text { Daily solar } \\
\text { radiation - tilted } \\
\mathrm{kWh} / \mathrm{m}^{2} / \mathrm{d}\end{array}$ & $\begin{array}{c}\text { Electricity } \\
\text { export rate } \\
\text { AED/MWh }\end{array}$ & $\begin{array}{l}\text { Electricity } \\
\text { exported t } \\
\text { grid } \\
\text { MWh }\end{array}$ \\
\hline January & 3.65 & 4.53 & 230.0 & 0.913 \\
\hline February & 4.37 & 5.06 & 230.0 & 0.912 \\
\hline March & 5.21 & 5.56 & 230.0 & 1.096 \\
\hline April & 6.15 & 6.07 & 230.0 & 1.136 \\
\hline May & 6.71 & 6.24 & 230.0 & 1.186 \\
\hline June & 6.69 & 6.05 & 230.0 & 1.105 \\
\hline July & 6.22 & 5.71 & 230.0 & 1.073 \\
\hline August & 6.02 & 5.79 & 230.0 & 1.082 \\
\hline September & 5.67 & 5.87 & 230.0 & 1.068 \\
\hline October & 4.88 & 5.53 & 230.0 & 1.057 \\
\hline November & 4.00 & 4.91 & 230.0 & 0.929 \\
\hline December & 3.39 & 4.29 & 230.0 & 0.859 \\
\hline Annual & 5.25 & 5.47 & 230.00 & 12.416 \\
\hline
\end{tabular}

Table 2: PV details

Photovoltaic
Type
Power capacity
Hanufacturer
Hodel
Efficiency
Nominal operating cell temperature
Temperature coefficient
Solar collector area

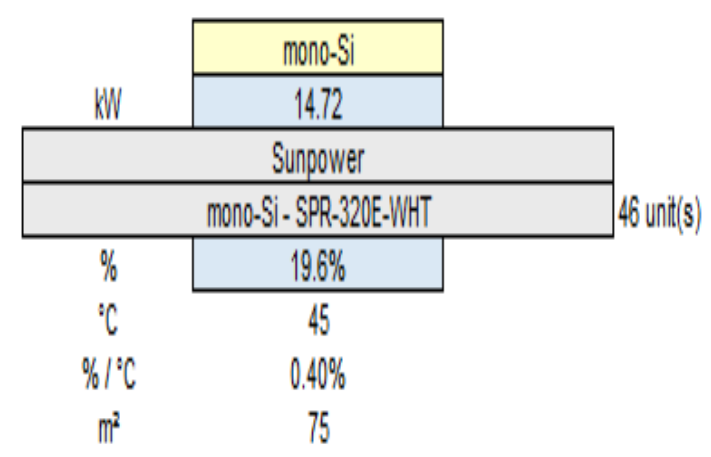


The table 2 shown above shows that the mono silicon PV is used due to its high efficiency and cost. Here 46 units of PV panels each with $320 \mathrm{~W}$ are used making it to $14.7 \mathrm{KW}$. Though the average power required is around $4 \mathrm{KW}$ the PV system is designed for $14 \mathrm{KW}$ as the efficiency of panels is around $20 \%$ and any extra power generated is connected to grid. In this case inverter with a capacity of $15 \mathrm{KW}$ is used to convert the obtained DC to AC voltage.

\begin{tabular}{ccc}
$\begin{array}{c}\text { Base case } \\
\text { GHG emission } \\
\text { tCO2 }\end{array}$ & $\begin{array}{c}\text { Proposed case } \\
\text { GHG emission } \\
\text { tCO2 }\end{array}$ & $\begin{array}{c}\text { Gross annual } \\
\text { GHG emission } \\
\text { reduction } \\
\text { tCO2 }\end{array}$ \\
\hline 5.3 & 0.1 & 5.2
\end{tabular}

Electricity contributes $38 \%$ of $\mathrm{C} 02$ emission compared with the industry which is $32 \%$ and Industry which is $14 \%$. The figure 7 shown below shows that the emission increases every year significantly. The green line indicates that the status of CO2 emission in the Middle East. The base case which is the load connected would produce 5.2 tons of carbon dioxide as per the RET screen software which can be eliminated by implementing PV system.

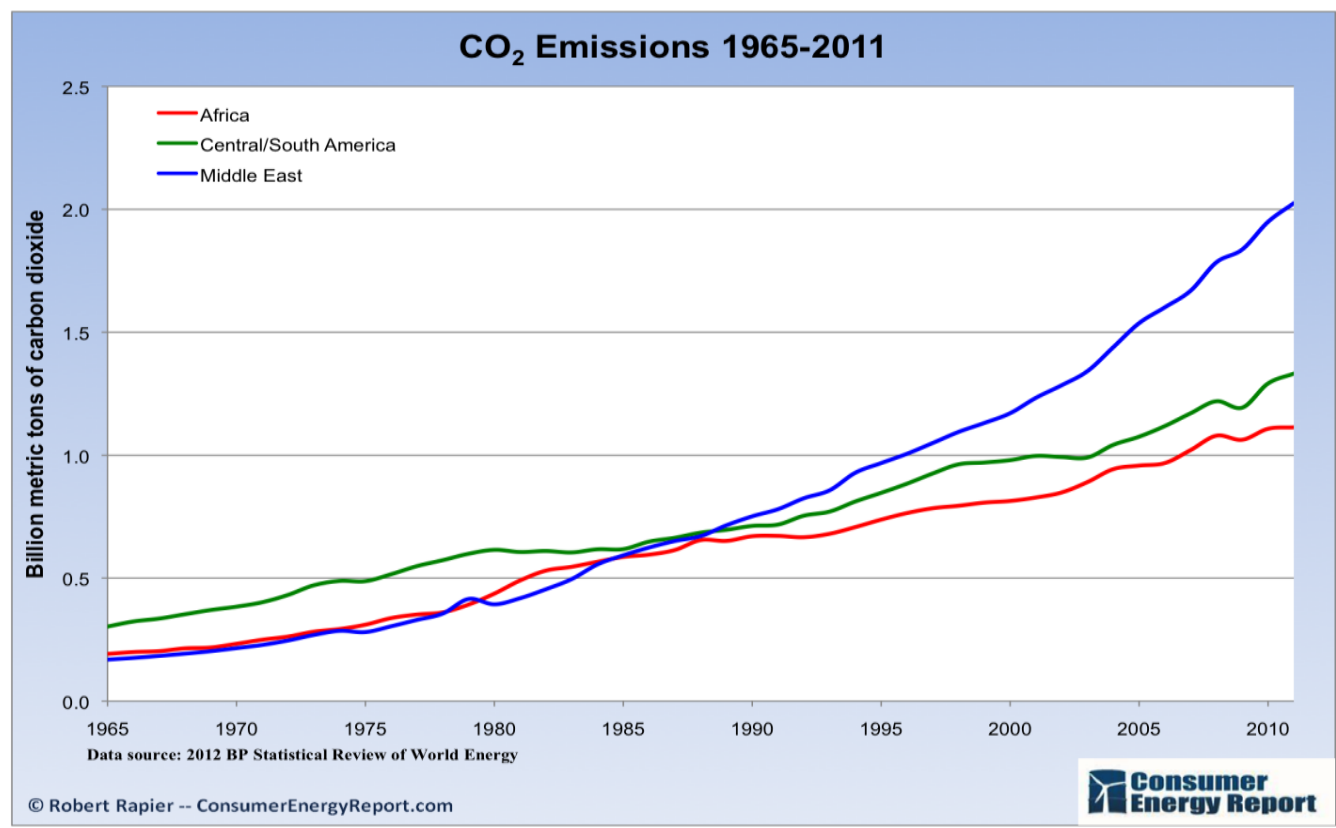

Fig 7: CO2 emission Analysis

Table 3: Engineering Operation and Maintenance

\begin{tabular}{|c|c|c|c|c|c|c|c|}
\hline \multicolumn{8}{|l|}{ Engineering } \\
\hline Engineering & cost & 1 & AED & 9,000 & AED & 9,000 & \\
\hline Subtotal: & & & & & AED & 9,000 & $7.1 \%$ \\
\hline \multicolumn{8}{|l|}{ Power system } \\
\hline Base load - Photovoltaic & kW & 14.72 & AED & 3,000 & AED & 44,160 & \\
\hline Peak load - Grid electricity & kW & 4.86 & AED & - & AED & - & \\
\hline Road construction & $\mathrm{km}$ & 0 & AED & - & AED & - & \\
\hline Transmission line & $\mathrm{km}$ & 0 & AED & 180,000 & AED & - & \\
\hline Substation & project & 0 & & & AED & - & \\
\hline Energy efficiency measures & project & 1 & AED & 3,000 & AED & 3,000 & \\
\hline \multirow[t]{2}{*}{\begin{tabular}{|l} 
User-defined \\
\end{tabular}} & cost & 3 & AED & 10,000 & AED & 30,000 & \\
\hline & & 1 & AED & 4,000 & AED & 4,000 & \\
\hline Subtotal: & & & & & AED & 81,160 & $64.4 \%$ \\
\hline \multicolumn{8}{|c|}{ Balance of system \& miscellaneous } \\
\hline Spare parts & $\%$ & $100.0 \%$ & AED & 300 & AED & 300 & \\
\hline Transportation & project & 1 & AED & 3,000 & AED & 3,000 & \\
\hline Training \& commissioning & $p-d$ & 2 & AED & 1,000 & AED & 2,000 & \\
\hline User-defined & cost & 1 & AED & 18,000 & AED & 18,000 & \\
\hline Contingencies & $\%$ & $10.0 \%$ & AED & 114,460 & AED & 11,446 & \\
\hline Interest during construction & $2.25 \%$ & 1 month(s) & AED & 125,906 & AED & 118 & \\
\hline Subtotal: & & & & & AED & 34,864 & $27.7 \%$ \\
\hline tal initial costs & & & & & AED & 126,024 & $100.0 \%$ \\
\hline
\end{tabular}

The table 3 shows that cost analysis for engineering work to be carried out the power system part which includes the solar panels, construction costs, spare parts, transportation costs were all taken in to account. 


\section{CONCLUSION}

In this paper the design of photovoltaic system for an green house is implemented. Optimum numbers of panels, inverters are selected. The cost analysis, risk analysis were also done using the RET Screen software. The figure 8 shown below shows the cash flow analysis. The $\mathrm{x}$-axis shows the year and the y-axis shows the cash flow. It has been observed that the break-even point is reached after sixteen years. It can be seen that the initial cost is around 100000 AED and the profit is shown until 25 years. The analysis is made for 25 years since the life span of the PV system is approximately 25 years.

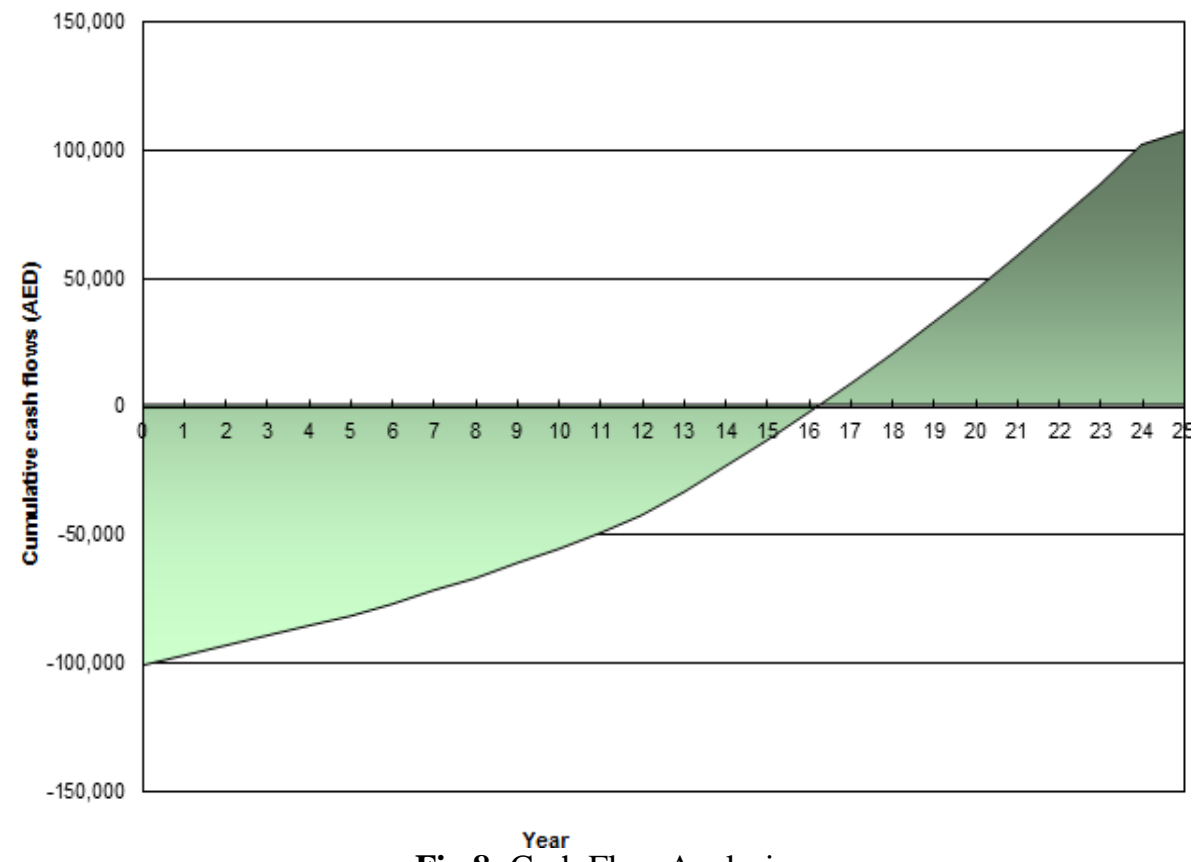

Fig 8: Cash Flow Analysis

\section{REFERENCES}

[1] Sujit Kumar Jha, Application of Solar Photovoltaic in Oman-Overview of Technology, Opportunities and Challenges, International Journal of Renewable Energy Research, Vol.3, No.2, 2013.

[2] F. Touati, A. Massoud, J. Abu Hamad and S.A. Saeed, Effects of Environmental and Climatic Conditions on PV Efficiency in Qatar, International Conference on Renewable Energies and Power Quality (ICREPQ'13), Bilbao (Spain), 20th to 22th March, 2013

[3] http://www.pveducation.org/pvcdrom/appendices/so lar-cell-efficiency-results2

[4] Dominique Bonkoungou,, Zacharie Koalaga, Donatien Njomo, Modelling and Simulation of photovoltaic module considering single-diode equivalent circuit model in MATLAB, International Journal of Emerging Technology and Advanced Engineering, Volume 3, Issue 3, March 2013, pp.493-502.

[5] E.M.G. Rodrigues, R. Melício1, V.M.F. Mendes, J.P.S. Catalão, International Conference on Renewable Energy and Power Technologies, April 2011, Spain.

[6] M. Mani and R. Pillai, "Impact Of dust on photovoltaic (PV) performance: research status, challenges and recommendations", Renewable and Sustainable Energy Reviews Vol. 14, pp. 31243131, 2010.
[7] P.Y. Lim and C.V. Nayar, "Solar irradiance and load demand forecasts in the supervisory control for offgrid hybrid energy system", In Proc. International Renewable Energy Congress, pp. 321-325, 2010.

\section{BIOGRAPHY}

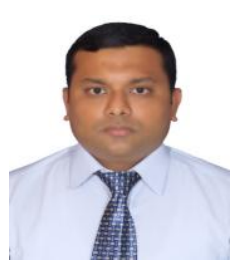

Dr.Swaroop is presently working as Asst Prof in the department of Electronics and Telecom at Amity University, Dubai. Swaroop obtained his $\mathrm{PhD}$ (Engg) in the areas of Electronics-Instrumentation and Control from Jadavpur University, Kolkata in 2005, and Master of Engineering in Control Systems from Birla Institute of Technology, Mesra, Ranchi in the year 2002. 